\title{
Comparison of Schwann Cells and Olfactory Ensheathing Cells for Peripheral Nerve Gap Bridging
}

\author{
Vincenzo Penna ${ }^{a} \quad$ G.-Bjoern Stark ${ }^{a}$ Konstantin Wewetzer ${ }^{b}$ d, e Christine Radtke \\ Eva M. Lang ${ }^{a, f}$ \\ ${ }^{a}$ Department of Plastic and Hand Surgery, University Medical Center Freiburg, Freiburg, Departments of \\ ${ }^{b}$ Functional and Applied Anatomy, and CPlastic, Hand and Reconstructive Surgery, Hannover Medical School, \\ ${ }^{\mathrm{d}}$ Department of Pathology, University of Veterinary Medicine, and e Center of Systems Neuroscience, Hannover, \\ and ${ }^{\mathrm{f}}$ Plastic and Hand Surgery, Evangelisches Krankenhaus, Zweibrücken, Germany
}

\section{Key Words}

Nerve conduit - Biogenic conduit · Schwann cell • Olfactory ensheathing cell $\cdot$ Sciatic functional index $\cdot$ Nerve gap

\begin{abstract}
Introduction: Previously, we introduced the biogenic conduit $(\mathrm{BC})$ as a novel autologous nerve conduit for bridging peripheral nerve defects and tested its regenerative capacity in a short- and long-term setting. The aim of the present study was to clarify whether intraluminal application of regeneration-promoting glial cells, including Schwann cells (SC) and olfactory ensheathing cells (OEC), displayed differential effects after sciatic nerve gap bridging. Material and Methods: BCs were generated as previously described. The conduits filled with fibrin/SC $(n=8)$ and fibrin/OEC $(n=8)$ were compared to autologous nerve transplants (NT; $n=8$ ) in the $15-\mathrm{mm}$ sciatic nerve gap lesion model of the rat. The sciatic functional index was evaluated every 4 weeks. After 16 weeks, histological evaluation followed regarding nerve area, axon number, myelination index and $\mathrm{N}$ ratio. Results: Common to all groups was a continual improvement in motor function during the observation period. Recovery was
\end{abstract}

significantly better after SC transplantation compared to OEC $(p<0.01)$. Both cell transplantation groups showed significantly worse function than the NT group $(p<0.01)$. Whereas nerve area and axon number were correlated to function, being significantly lowest in the OEC group $(p<$ $0.001)$, both cell groups showed lowered myelination ( $p<$ 0.001 ) and lower N ratio compared to the NT group. Discussion: $\mathrm{SC}$-filled $\mathrm{BC}$ s led to improved regeneration compared to OEC-filled BCs in a 15-mm-long nerve gap model of the rat.

Copyright $\odot 2012$ S. Karger AG, Basel

\begin{tabular}{ll}
\hline Abbreviations used in this paper \\
\hline BC & biogenic conduit \\
CNS & central nervous system \\
HBSS & Hanks' balanced salt solution \\
NT & autologous nerve transplants \\
OEC & olfactory ensheathing cells \\
PNS & peripheral nerve system \\
PVC & polyvinyl chloride \\
SC & Schwann cells \\
SFI & sciatic function index
\end{tabular}

\section{KARGER}

Fax +4161306 1234

E-Mail karger@karger.ch

www.karger.com
(C) 2012 S. Karger AG, Basel

$1422-6405 / 12 / 1966-0534 \$ 38.00 / 0$

Accessible online at:

www.karger.com/cto
Dr. Vincenzo Penna

Department of Plastic and Hand Surgery, University Medical Center Freiburg Hugstetter Strasse 55

DE-79106 Freiburg (Germany)

Tel. +49761 270 28170, E-Mail vincenzo.penna@uniklinik-freiburg.de 


\section{Introduction}

Therapeutic options in bridging of nerve defects are still limited. The most desirable repair is tension-free microsurgical coaptation. If the defect does not permit direct coaptation, the defect has to be bridged by an autologous nerve graft. Usually, superficial sensory nerves such as the sural nerve, saphenous nerve and medial antebrachial cutaneous nerve are used as nerve grafts [Terzis et al., 1997; Grant et al., 1999]. However, since this inevitably goes along with donor site morbidity and insufficient regeneration through these grafts, the search for alternative nerve conduits is still ongoing [Terzis et al., 1997; Grant et al., 1999]. Various nerve conduits have been studied regarding their regeneration-promoting properties: autologous blood vessels [Anderson and Turmaine, 1986; Battiston et al., 2000], muscle fibers [Battiston et al., 2000] and silicone [Doolabh et al., 1996]. Recently, biodegradable materials (e.g. polyglycolic acid, poly(lactide-co-glycolic) acid and polycaprolactone) were introduced [Meek and Coert, 2008]. All these conduits were shown to have variable success, suffer similar disadvantages like autografts and, moreover, all lack an intrinsic vascularization [Varejao et al., 2003]. Recently, we described the formation of a vascularized biogenic conduit (BC) and its use for bridging of large nerve gaps $(15 \mathrm{~mm})$ in the adult rat sciatic nerve lesion model [Penna et al., 2011, 2012]. The BC is permeable, flexible, does not elicit immunological response and is easy to handle and suture, thus being near to an ideal conduit [Belkas et al., 2004]. In surplus, BCs do have an intrinsic vascularization.

Intraluminal addition of supportive cells such as Schwann cells (SC) and olfactory ensheathing cells (OEC) are known to enhance regeneration through nerve conduits and to be indispensable for long nerve gap bridging [Sinis et al., 2005, 2007]. SC are probably the most extensively investigated supportive cells [Ansselin et al., 1997; Bryan et al., 2000; Galla et al., 2004; Hood et al., 2009]. Besides the production of a range of growth factors such as insulin-like growth factor I, ciliary neurotrophic factor, brain-derived neurotrophic factor and extracellular matrix molecules (e.g. laminin), SC do also mechanically support axonal outgrowth [Meyer et al., 1992]. OEC are the glial cells of the olfactory system that ensheath large fascicles of unmyelinated primary olfactory axons and support their continual entry into the central nervous system (CNS) throughout the life of mammals [RamonCueto and Avila, 1998; Boyd et al., 2005]. OEC have been shown to producea wide spectrum of cytokines [Wewetzer et al., 2001; Woodhall et al., 2001]. Unlike SC, OEC are present in both the olfactory nerves and bulb, and therefore, are constituents of the peripheral nerve system (PNS) and the CNS, respectively. It is well established that transplanted OEC modulate axonal growth in the CNS and PNS [Verdu et al., 1999; Franklin and Barnett, 2000; Guntinas-Lichius et al., 2001, 2002; Radtke et al., 2009a, 2009b]. However, due to the lack of comparative studies of OEC and SC, it is not yet clear whether OEC display advantages over SC for peripheral nerve repair [Wewetzer et al., 2002, 2011].

Therefore, the aims of the presented study were: (1) to apply OEC and SC in the same in vivo paradigm and to test whether both cell types display differential effects after sciatic nerve lesion, and (2) to clarify whether intraluminal application of $\mathrm{OEC}$ and $\mathrm{SC}$ into the $\mathrm{BC}$ can potentiate axonal regeneration across large gaps.

\section{Material and Methods}

A total of 24 adult female inbred Lewis rats (6-8 weeks old, 230-250 g body weight; Charles River, Sulzfeld, Germany) were divided into three experimental groups: group $1(n=8)$, autologous nerve transplant (NT); group $2(\mathrm{n}=8), \mathrm{BC}$ filled with OEC in fibrin matrix; group $3(n=8), B C$ filled with SC in fibrin matrix. Survival time was 16 weeks. The State Animal Protection Committee approved all experiments (registration number T-02/29). All measurements were performed by the first author using a blinded protocol.

In vivo Formation of the BCs

The $\mathrm{BC}$ was induced in a two-step surgical procedure as previously published [Penna et al., 2011, 2012]. Briefly, a 19-mm-long polyvinyl chloride (PVC) tube was implanted in the direct vicinity to the future transection site. After 4 weeks, the PVC tube was removed, revealing a connective tissue tube $(\mathrm{BC})$ that was then filled with fibrin/cells and used as a bridging device for the transected nerve (fig. 1).

\section{Cell Culture}

SC were isolated from neonatal inbred Lewis rats and expanded in culture using established protocols [Brockes et al., 1979; Wewetzer et al., 1996]. Briefly, 3- to 5-day-old rats were killed by decapitation and the sciatic nerves were removed. Enzymatic treatment was performed using trypsin $(0.25 \%$; Sigma, Deisenhofen, Germany) and collagenase A $0.1 \%$ (Roche Diagnostics, Penzberg, Germany) in Hanks' balanced salt solution (HBSS; GibcoBRL Life Technologies, Karlsruhe, Germany) for $35 \mathrm{~min}$ at $37^{\circ} \mathrm{C}$. Then, complete medium [Dulbecco's modified Eagle medium (GibcoBRL Life Technologies), 10\% fetal calf serum (PAA Laboratories, Linz, Austria), 1\% penicillin/streptomycin (GibcoBRL Life Technologies)] was added and the suspension was centrifuged $\left(1,000 \mathrm{rpm}, 4^{\circ} \mathrm{C}\right)$. Poly-L-Iysin-coated tissue culture flasks $\left(75 \mathrm{~cm}^{2}\right)$ were used. The day after, cultures were treated with cytosine- $\beta$-D-arabinofuranoside ( $1 \mu \mathrm{M}$; Sigma) for $72 \mathrm{~h}$ to 


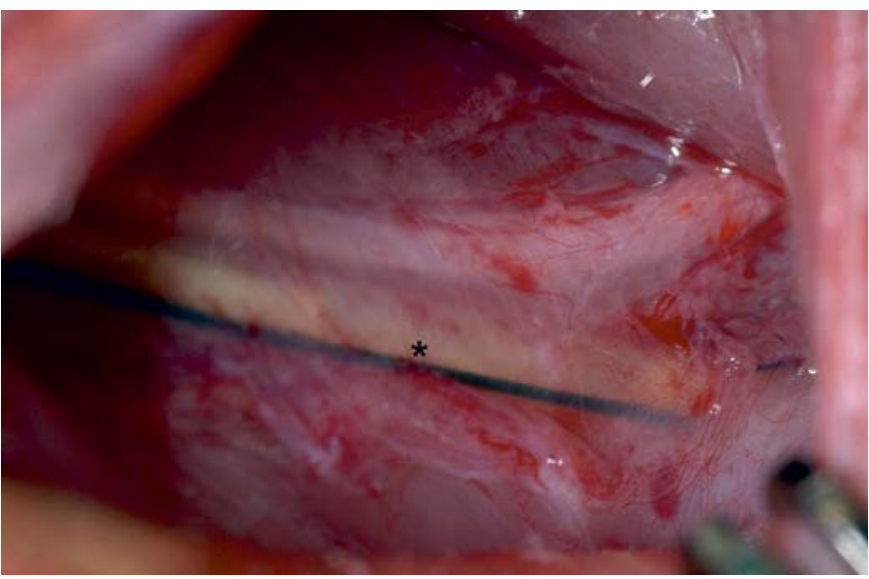

Fig. 1. Fibrous tissue formation (BC) around an implanted PVC tube (asterisk).

reduce proliferating fibroblasts. Proliferation of SC was stimulated by forskolin ( $1 \mu \mathrm{M}$; Calbiochem, La Jolla, Calif., USA). The cultures were incubated at $37^{\circ} \mathrm{C}$ in a humidified air atmosphere $\left(5 \% \mathrm{CO}_{2}\right)$ and the medium was changed every 2 days. Prior to implantation of SC, the forskolin concentration in the culture medium was continuously reduced over 9 days. SC were detached from the culture flasks using trypsin/EDTA and resuspended in the thrombin component of fibrin glue (Tissucol Duo $\mathrm{S}^{\circledR}$; Baxter, Vienna, Austria).

OEC were isolated from the above mentioned neonatal rats following established protocols [Guntinas-Lichius et al., 2001; Wewetzer et al., 2001; Woodhall et al., 2001; Brandes et al., 2011]. The olfactory bulbs were removed, washed twice in HBSS, diced into small fragments and incubated in HBSS with $0.125 \%$ trypsin, $0.03 \%$ collagenase A and $0.05 \%$ DNase I (Boehringer, Mannheim, Germany) for $45 \mathrm{~min}$ at $37^{\circ} \mathrm{C}$. Enzymatic treatment was stopped by adding complete medium, and the suspension was centrifuged $\left(1,000 \mathrm{rpm}, 4^{\circ} \mathrm{C}\right)$. Poly-L-Iysin-coated tissue culture flasks (75 $\mathrm{cm}^{2}$ ) were used. Further processing was performed as described above for SC.

\section{Sciatic Nerve Transection and Bridging Procedures}

The animals were anesthetized with isoflurane and the sciatic nerve was exposed as previously published [Penna et al., 2011, 2012]. A $15-\mathrm{mm}$ nerve segment was resected at $95 \mathrm{~mm}$ proximally of the 3rd toe with the leg outstretched. In order to bridge the nerve gap using a nerve graft (group 1), the resected nerve segment was coapted proximally and distally with two 11-0 nylon single stitches. The bridging of the sciatic nerve gap with the $\mathrm{BC}$ (groups 2-3) was initiated by the removal of the PVC tube. While removing the tube, 2-component fibrin glue TissuCol S Duo (25 $\mu \mathrm{l}$; Baxter) was simultaneously injected in order to avoid conduit collapse [Penna et al., 2011, 2012]. In groups 2 and 3, a total of 0.5 $\times 10^{6}$ cells $/ 12.5 \mu \mathrm{l}$ thrombin was used [Horch et al., 1998; Bach et al., 2001]. The proximal and distal nerve stumps were telescoped $2 \mathrm{~mm}$ into each opening of the BC, leaving a 15-mm-long gap between the proximal and distal nerve stump. The nerve segments on either end were secured to the BC using 11-0 nylon epineural sutures (fig. 2).

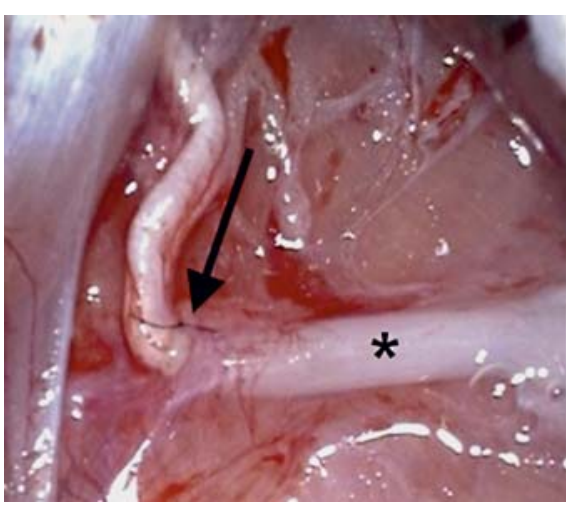

Fig. 2. BC (asterisk) with inserted distal nerve stump (arrow).

The skin incision was closed with 4-0 vicryl running suture, and the animals were placed in a controlled environment to recover. Postoperative analgesia was obtained by subcutaneous injections of Rimadyl ${ }^{\circledR}$ (Pfizer, Karlsruhe, Germany) and Temgesic $^{\circledR}$ (Essex Pharma, Munich, Germany).

\section{Assessment of Motor Function}

Impairment of motor function was evaluated by walking track analysis at 4, 8, 12 and 16 weeks postoperatively and expressed as the sciatic function index (SFI) [Penna et al., 2011, 2012]. Indian ink was applied to the plantar surface of the hind feet to cover all anatomical regions. The rats that had been trained prior to surgery were allowed to walk down a track leaving footprints on the paper. These prints were then used to calculate the SFI that ranges from 0 (normal) to -100 (total functional loss).

\section{Histological Procedures}

After 16 weeks survival time, the rats were sacrificed and the tissue samples were processed as previously published [Penna et al., 2011, 2012]. Briefly, after transcardial perfusion fixation, the middle parts of the nerve samples were embedded in araldite. Cross sections $(1 \mu \mathrm{m})$ were cut and stained with methylene blue. The nerve area, axon numbers, myelination index (axon area/myelin area) and $\mathrm{N}$ ratio (total myelinated fiber area/nerve area) were obtained by conventional light-microscopic examination with the computer-assisted AxioVision $^{\circledR}$ 2.0.5 system (Carl Zeiss Vision, Munich, Germany). Axon number was determined manually by counting every identifiable axon in $\times 100$ magnification. To assess the myelination index and $\mathrm{N}$ ratio, all axon areas and myelin areas in three randomly chosen regions of interest $\left(10,000 \mu \mathrm{m}^{2}\right)$ were measured [Schroder et al., 1993; Penna et al., 2011, 2012].

\section{Statistical Analysis}

All data were statistically analyzed with the use of SPSS ${ }^{\circledR}$ Software version 8.0 (SPSS, Munich, Germany). The results are expressed as mean $\pm \mathrm{SD}$. Comparisons between the groups were made by one-way analysis of variance followed by Tukey's posthoc test or Student's t test. A p $<0.05$ was considered statistically significant. 


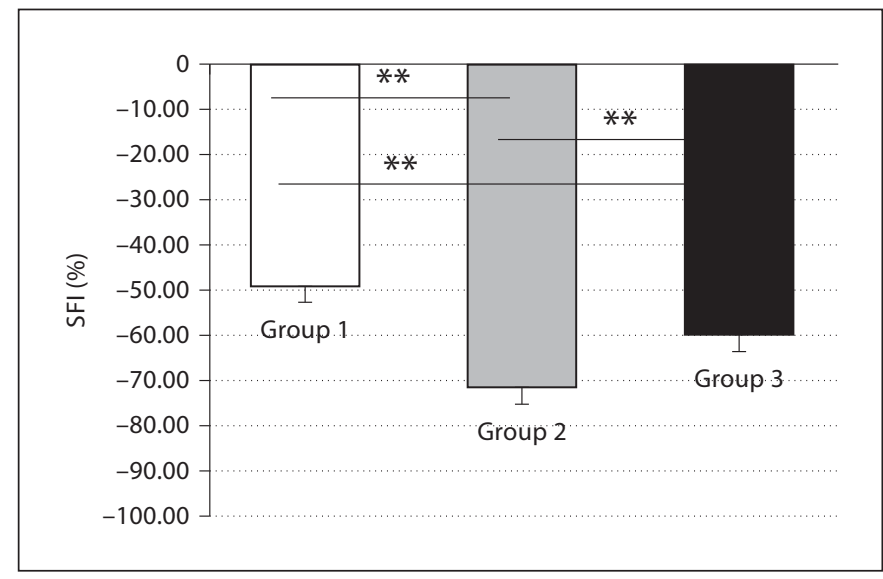

Fig. 3. SFI after 16 weeks. Group $1=\mathrm{NT}$; group $2=\mathrm{BC}$ filled with OEC in fibrin matrix; group $3=\mathrm{BC}$ filled with $\mathrm{SC}$ in fibrin matrix. ** $\mathrm{p}<0.01$.

\section{Results}

\section{General Observations}

None of the animals showed signs of automutilation or infection. All animals underwent functional and histological analyses.

\section{Sciatic Functional Index}

All operated rats showed impaired fluency of walking, foot placement and swing phase, while contractions of the hindpaws were absent. During the first 12 weeks, no statistical significance between the groups could be detected. After 16 weeks, groups 1 and 3 showed significantly $(\mathrm{p}<0.01)$ better clinical function than the OEC group (group 2) (fig. 3).

\section{Histomorphological Evaluation}

All groups displayed a predominance of axon areas between 5 and $20 \mu \mathrm{m}^{2}$. Statistical analysis of axon area distribution did not show any significance between all groups (fig. 4).

Measurements of nerve cross-sectional areas revealed significantly lowest values for group $2(122,567 \pm 27,440$ $\left.\mu \mathrm{m}^{2}\right)$ compared to group $1\left(407,990 \pm 38,362 \mu \mathrm{m}^{2}\right)$ and group $3\left(238,428 \pm 67,011 \mu \mathrm{m}^{2} ; \mathrm{p}<0.001\right)$ (fig. 5). Regeneration through NT led to a significantly higher axon number $(10,719 \pm 1,000)$ compared to group $2(\mathrm{p}<0.001)$ with $1,614 \pm 413$ axons and to group $3(\mathrm{p}<0.05)$ with $4,006 \pm 1,515$ axons (fig. 6). After 16 weeks, myelination in all groups showed a statistically significant difference $(\mathrm{p}<0.001)$, with most reduced myelination in group 2
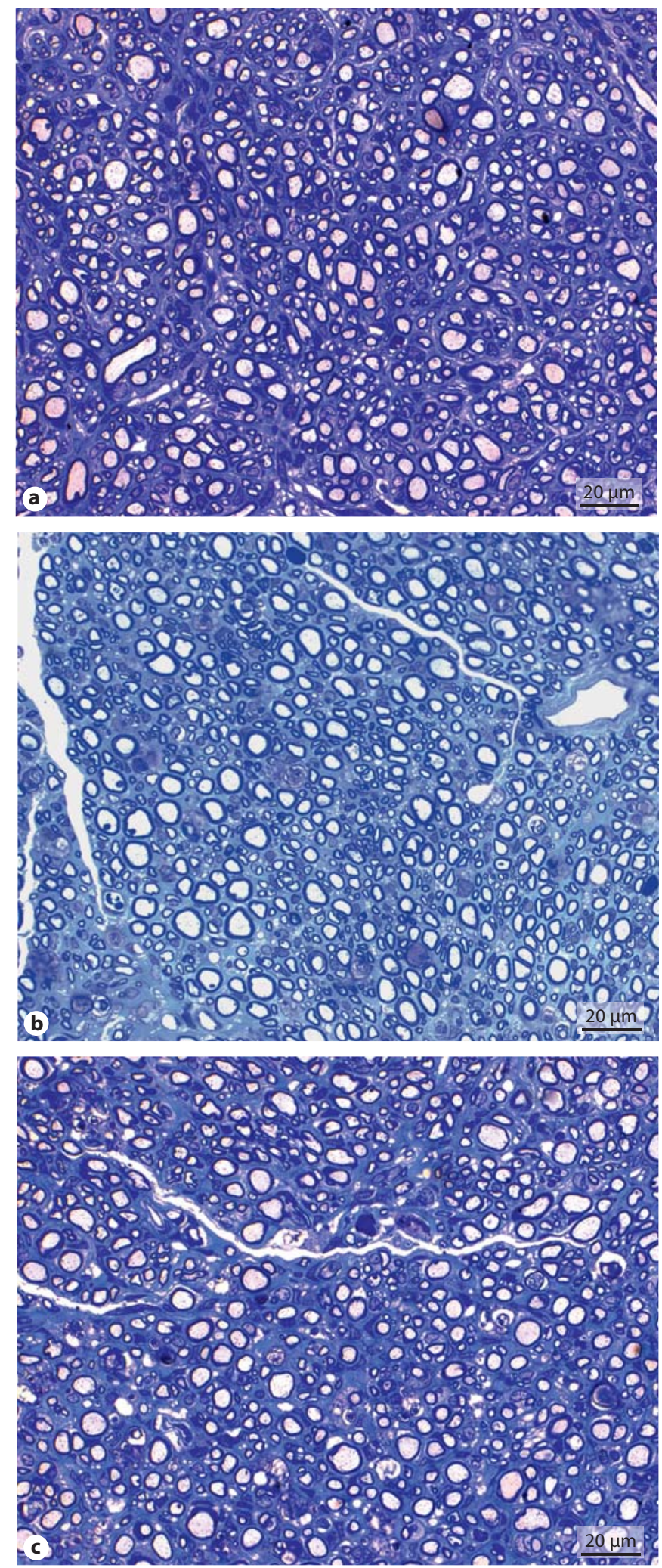

Fig. 4. Methylene blue-stained cross-cuts (middle part of the nerve samples). a NT. b BC filled with OEC in fibrin matrix. c BC filled with SC in fibrin matrix. 


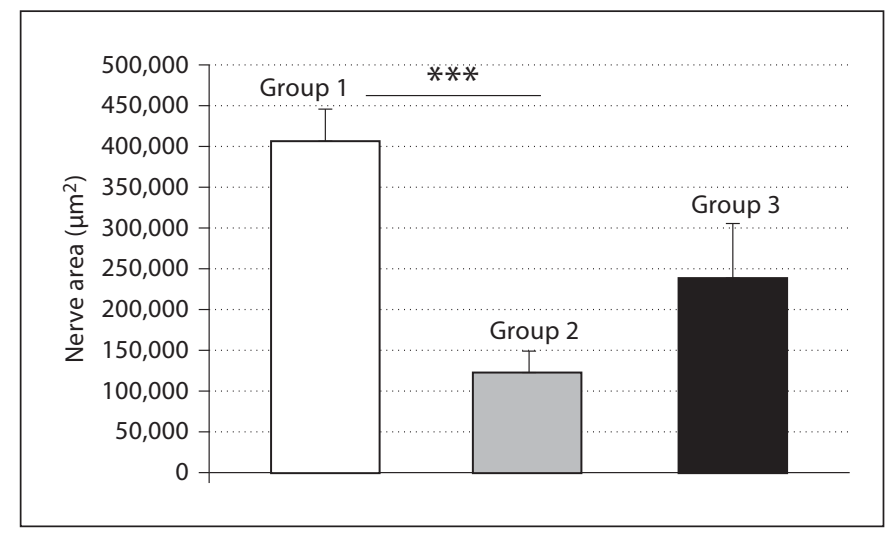

Fig. 5. Nerve area after 16 weeks. Group definitions are given in figure $3 .{ }^{* *} \mathrm{p}<0.001$.

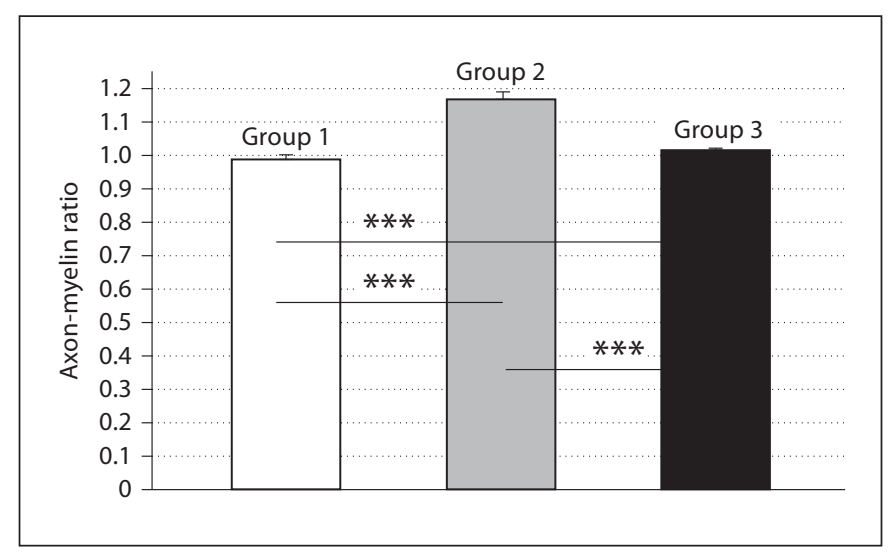

Fig. 7. Axon-myelin ratio after 16 weeks. Group definitions are given in figure $3 .{ }^{* *} \mathrm{p}<0.001$.

$(1.17 \pm 0.02)$ compared to group $1(0.99 \pm 0.01)$ and group $3(1.02 \pm 0.01)$ (fig. 7). The $\mathrm{N}$ ratio is an indicative of the intraneural amount of fibrous tissue. A low $\mathrm{N}$ ratio goes along with a high amount of fibrous tissue. The $\mathrm{N}$ ratios in groups $2(0.29 \pm 0.02)$ and $3(0.30 \pm 0.01)$ were significantly lower than in group $1(0.35 \pm 0.01 ; \mathrm{p}<0.05)$ (fig. 8).

\section{Discussion}

Axonal growth-promoting effects of SC and OEC in CNS and PNS injuries are well described in the literature [Bunge, 1994; Boyd et al., 2005; Hood et al., 2009; Radtke et al., 2009b]. Comparisons of both cell lines have been

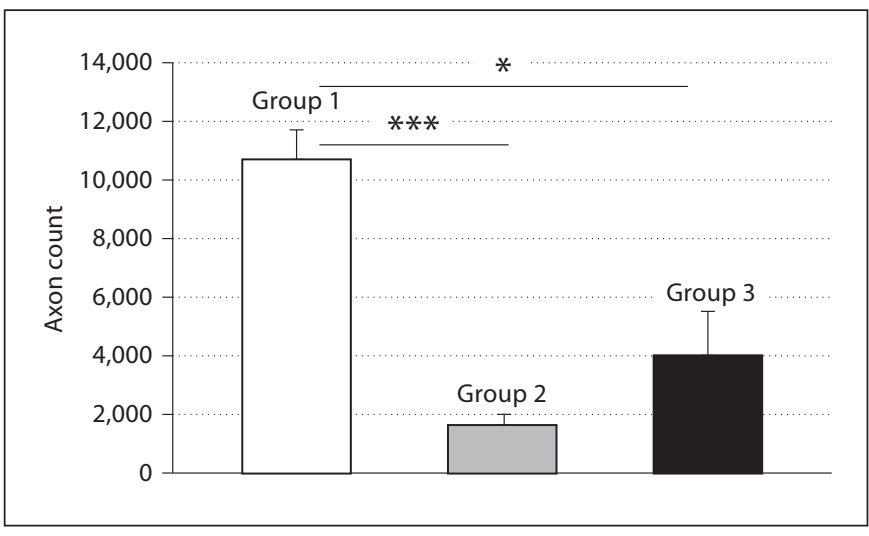

Fig. 6. Axon number after 16 weeks. Group definitions are given in figure $3 .{ }^{*} \mathrm{p}<0.05 ;{ }^{* *} \mathrm{p}<0.001$.

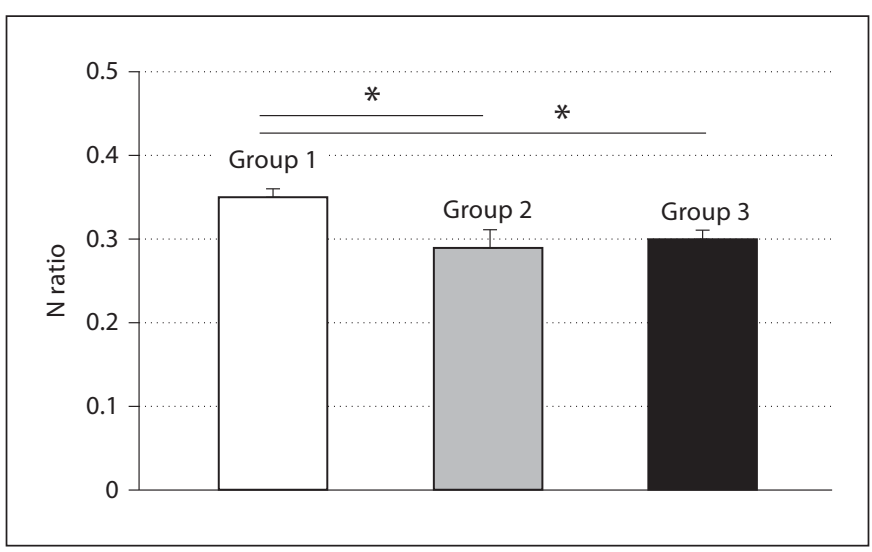

Fig. 8. $\mathrm{N}$ ratio after 16 weeks. Group definitions are given in figure $3 .{ }^{*} \mathrm{p}<0.05$.

described in CNS lesions; the results range from a found advantage of the use of OEC [Lakatos et al., 2000], advantage of the use of SC [Takami et al., 2002], up to no found difference between both cell lines [Imaizumi et al., 2000]. In PNS lesions, several studies using either SC or OEC show positive effects on regeneration [Bunge, 1994; Radtke et al., 2009b; Guerout et al., 2011a].

Whether OEC keep their character after implantation or undergo differentiation has not yet been shown. Microarray analyses revealed that purified cell cultures of OEC and SC display differential gene expression [Franssen et al., 2008; Roet et al., 2011]. However, so far, no specific molecular marker for in vitro or in situ detection of OEC and SC has emerged from these studies. It is well known that OEC in vitro [Devon and Doucette, 1992; Ba- 
biarz et al., 2011] and in vivo [Radtke et al., 2004; Sasaki et al., 2004] produce peripheral-type myelin and express SC-specific transcription factors [Smith et al., 2001]. However, both criteria apply also to SC. Thus, the question of whether OEC may alter their phenotype after transplantation will not be answered until specific markers for OEC are identified.

A direct comparison of both cell lines in PNS lesions has never been described before. Therefore, one aim of this study was to perform a direct comparison of the regeneration potency of SC and OEC. Neither nerve area nor axon number revealed a significant difference between the SC and OEC groups. However, myelination was significantly better in the SC group. This correlated also to clinical function (SFI); here, the SC group showed less impairment of sciatic function than the OEC group. SC are known to produce various growth factors such as nerve growth factor, brain-derived neurotrophic factor, ciliary neurotrophic factor and glial cell line-derived neurotrophic factor [Bandtlow et al., 1987; Acheson et al., 1991; Friedman et al., 1992; Rende et al., 1992; Widenfalk et al., 2001]. Although OEC share properties of SC and they are a distinct cell type which produce a range of neurotrophic factors [Ramon-Cueto and Avila, 1998; Lakatos et al., 2000; Wewetzer et al., 2002; Wewetzer and Brandes, 2006; Radtke and Wewetzer, 2009; Radtke et al., 2010, 2011], there are reports that the excretion of OEC of neurotrophic factors is reduced compared to SC [RamonCueto and Avila, 1998]. Thus, the observed difference in regeneration could be the cause of reduced ability of interaction of OEC in the PNS with diminished release of neurotrophic factors. Recently, Guerout et al. [2011b] could show that only co-transplantation of OEC obtained from olfactory mucosa and bulbs supported a major functional recovery in the PNS. As we used bulbar OEC, this could in part explain our results.

The in vivo tissue-engineered $\mathrm{BC}$ is a biological material, and thus, fulfills the ideal conduit qualities like biocompatibility, biodegradability, non-toxicity and permeability for nutrients. In surplus, it is highly vascularized. The striking difference of $\mathrm{BC}$ in comparison to all other artificial conduits is its intrinsic vascularization from the very first moment of its use as a nerve conduit. When nerve grafts are used to bridge large nerve gaps, these grafts undergo centrifascicular fiber degeneration with impaired SC viability once a critical size is exceeded [Tarlov and Epstein, 1945; Best and Mackinnon, 1994]. This is due to microvascular blood flow as a critical limiting factor for graft survival [Hobson et al., 1997, 2000]. Vascularized nerve grafts diminish endoneurial scarring by maintaining the endoneurial cell population viable and thus providing an optimal nutritional environment that result in an increased rate of axonal regeneration [Terzis et al., 1995]. Without blood vessels entering the graft from the surrounding tissue and both stumps, the mid-portion of these grafts undergoes necrosis with subsequent fibrosis [Lundborg, 1982]. The vascularized BC increases blood supply at the site of nerve regeneration by its intrinsic vascularization from the very beginning. As normal revascularization of transected nerves relies on sprouting processes of the proximal stump, the $\mathrm{BC}$ might entail a time advantage. Despite the intrinsic vascular system of $\mathrm{BC}$, revascularization occurs through intraluminal axonal and vascular outgrowth from the proximal stump and vascular outgrowth from the distal stump [Hobson et al., 2000].

Regarding the clinical use, the major disadvantage of the BC is its necessity of a two-step approach, whereas autologous grafts can be applied in a single-step operation, leading to an unwanted delay of nerve regeneration. In cases of extensive soft tissue damage, a several-step surgical approach (even using free tissue transfer) with restoration of good vascularized soft tissue is compulsory. Thus, this 2-step approach could be integrated in the surgical planning without delaying nerve repair [Penna et al., 2011, 2012]. Recent developments in conduit design include the incorporation of topographical guidance features and/or intraluminal structures, which attempt to guide SC migration and axonal regrowth towards their distal targets. This indeed seems to be another promising step towards the ideal nerve conduit. However, this approach is not evaluated in the present manuscript, where only fibrin/cell-filled conduits are used. The combination of the highly vascularized conduit, together with intraluminal guidance structures, might be an interesting question to be answered in a further study.

In previously published studies, the regenerational capability of the BC was analyzed in a short- (4 weeks) and long-term (16 weeks) setting. The NT being the gold standard for nerve gap bridging was histologically and functionally compared to the BC [Penna et al., 2011, 2012]. The studies showed that BCs were permissive for nerve regeneration over a period of several months without being degraded and without showing signs of shrinking or excessive fibroblastic intraluminal infiltration. Although $\mathrm{BC}$ bridging lead to almost comparable regeneration results to NT, there is still optimization potential. Since transplantation of axon growth-supporting cells is known to enhance peripheral nerve regeneration [Galla et al., 2004; Hood et al., 2009; Radtke et al., 2009a, 2011], the 
presented study evaluated whether the intraluminal addition of OEC and SC potentiated axonal regeneration. The cell-filled BCs remained identifiable at 16 weeks survival time resembling a normal epineurial layer. Histomorphometric analysis showed complete axonal regeneration throughout the BCs with significant lower axon number and $\mathrm{N}$ ratio in both $\mathrm{BC}$ groups and significantly reduced nerve area in the OEC group compared to the autologous nerve conduit group. These results are in agreement with the previously published short-term (4 weeks) and long-term data in the literature, which describe lower axon numbers, nerve areas and $\mathrm{N}$ ratio in groups with nerve gap bridging using BCs, biological or artificial nerve conduits [Mackinnon and Dellon, 1990; Battiston et al., 2000; Varejao et al., 2003; Penna et al., 2011, 2012]. Myelination in both cell groups was significantly reduced after 16 weeks, with most impaired myelination in the OEC group. In order to analyze intraneural fibroblastic infiltration, the $\mathrm{N}$ ratio as indicative of a intraneural amount of fibrous tissue was measured. Both cell-filled BC groups showed lower N ratios than the NT group. These results correlate with the previously published short- and long-term results with $\mathrm{N}$ ratios of 0.28 \pm 0.2 (4 weeks) and $0.30 \pm 0.01$ (16 weeks) in fibrin-filled BCs [Penna et al., 2011, 2012]. Thus, fibroblastic infiltration does not seem to be altered with the intraluminal addition of cells. Clinical function (SFI) was most reduced in the OEC group, while comparison of the SC group and the NT group revealed no statistical significance. This result is of particular interest, as the SFI testing in the short- and long-term studies of fibrin-filled BCs did not reveal any differences compared to the NT group.

Thus, based upon our findings, the intraluminal addition of SC and OEC to the BC did not enhance regeneration. Nerve area and axon number were as reduced as in the cell-free BCs. The long-term evaluation of the fibrin-filled BC showed equal myelination compared to the NT. Surprisingly, the addition of SC and OEC that are supposed to enhance myelination led to reduced myelination. Possible reasons for these findings could be that the high vascularization of $\mathrm{BC}$ affects intraluminal nutrition of the cells, resulting in high proliferation rates [Penna et al., 2011]. This could lead to an increase in total intraluminal cell number, which could mechanically hinder axonal sprouting. Optimal vascularization could also increase fibroblastic activity, leading to intraneural scarring and impeding regeneration. This possibility is less likely, as the used cells showed purity of around 99\% so that the fibroblastic fraction is negligible. In surplus, comparison of the $\mathrm{N}$ ratios in both cell-filled BCs compared to only fibrin-filled BCs revealed no difference. The number of cells could also be of importance when interpreting the results. In the presented study, 500,000 cells/conduit were used, which equals 20 million cells/ $\mathrm{ml}$. Ansselin et al. [1997] examined the effect of increasing SC numbers on peripheral nerve regeneration. The initially found advantage of higher cell numbers could not be detected after 3 months. Verdú et al. [1999] used $120,000 \mathrm{OEC} /$ conduit which equals 2.4 million cells $/ \mathrm{ml}$, showing successful nerve regeneration. Thus, the cell concentration used in this study lies in a range with which good regeneration results can be obtained. Another possibility could be that the intraluminal cells do not survive. However, this is not very likely, as the literature shows.

Fansa et al. [2001] could show that SC survive up to 7 days in autologous grafts without blood supply, depending purely on diffusion. Engineered grafts showed a delayed revascularization, starting between day 5 and day 7 in comparison to normal autografts that revascularized by day 3. However, as vascular structure in engineered grafts is established between day 5 and day 7 , this time period is long enough to support cell survival. Thus, if considering these findings, our cells indeed depend on diffusion for the first days but then are rapidly supplied by a vascular system depending on both internal and external (BC) processes. We did not perform a labeling of the cells prior to implantation in order to evaluate cell mobility. This for sure would have been of some interest. However, Kim et al. [1994] and Lin et al. [2011] could show that transplanted cells in conduits remain stationary and survive up to 1 year after implantation. Regarding the intraluminal cell distribution, literature shows that cells are homogenously distributed throughout the matrix (e.g. fibrin) [Galla et al., 2004; Kalbermatten et al., 2008].

It might be of interest to evaluate the regeneration capability of BC with the intraluminal application of stem cells in a future study design.

In conclusion, intraluminal SC application led to significantly better regeneration compared to the use of bulbar OEC in the presented model. The direct comparison of both cell types in a non-vascularized conduit and with the use of bulbar and mucosal OEC is warranted in further studies. 


\section{References}

-Acheson, A., P.A. Barker, R.F. Alderson, F.D. Doolabh, V.B., M.C. Hertl, S.E. Mackinnon Miller, R.A. Murphy (1991) Detection of brain-derived neurotrophic factor-like activity in fibroblasts and Schwann cells: inhibition by antibodies to NGF. Neuron 7: 265275.

Anderson, P.N., M. Turmaine (1986) Axonal regeneration through arterial grafts. J Anat 147: 73-82.

Ansselin, A.D., T. Fink, D.F. Davey (1997) Peripheral nerve regeneration through nerve guides seeded with adult Schwann cells. Neuropathol Appl Neurobiol 23: 387-398.

-Babiarz, J., N. Kane-Goldsmith, S. Basak, K. Liu, W. Young, M. Grumet (2011) Juvenile and adult olfactory ensheathing cells bundle and myelinate dorsal root ganglion axons in culture. Exp Neurol 229: 72-79.

Bach, A.D., H. Bannasch, T.J. Galla, K.M. Bittner, G.B. Stark (2001) Fibrin glue as matrix for cultured autologous urothelial cells in urethral reconstruction. Tissue Eng 7: 45-53.

Bandtlow, C.E., R. Heumann, M.E. Schwab, H. Thoenen (1987) Cellular localization of nerve growth factor synthesis by in situ hybridization. EMBO J 6: 891-899.

Battiston, B., P. Tos, S. Geuna, M.G. GiacobiniRobecchi, R. Guglielmone (2000) Nerve repair by means of vein filled with muscle grafts. 2. Morphological analysis of regeneration. Microsurgery 20: 37-41.

Belkas, J.S., M.S. Shoichet, R. Midha (2004) Peripheral nerve regeneration through guidance tubes. Neurol Res 26: 151-160.

-Best, T.J., S.E. Mackinnon (1994) Peripheral nerve revascularization: a current literature review. J Reconstr Microsurg 10: 193-204.

Boyd, J.G., R. Doucette, M.D. Kawaja (2005) Defining the role of olfactory ensheathing cells in facilitating axon remyelination following damage to the spinal cord. Faseb J 19: 694703.

Brandes, G., M. Khayami, C.T. Peck, W Baumgartner, H. Bugday, K. Wewetzer (2011) Cell surface expression of 27C7 by neonatal rat olfactory ensheathing cells in situ and in vitro is independent of axonal contact. Histochem Cell Biol 135: 397-408.

Brockes, J.P., K.L. Fields, M.C. Raff (1979) Studies on cultured rat Schwann cells. 1. Establishment of purified populations from cultures of peripheral nerve. Brain Res 165: 105118.

Bryan, D.J., A.H. Holway, K.K. Wang, A.E. Silva, D.J. Trantolo, D. Wise, I.C. Summerhayes (2000) Influence of glial growth factor and Schwann cells in a bioresorbable guidance channel on peripheral nerve regeneration. Tissue Eng 6: 129-138.

Bunge, R.P. (1994) The role of the Schwann cell in trophic support and regeneration. J Neurol 242 (suppl 1): S19-S21.

Devon, R., R. Doucette (1992) Olfactory ensheathing cells myelinate dorsal root ganglion neurites. Brain Res 589: 175-179. (1996) The role of conduits in nerve repair: a review. Rev Neurosci 7: 47-84.

Fansa, H., W. Schneider, G. Keilhoff (2001) Revascularization of tissue-engineered nerve grafts and invasion of macrophages. Tissue Eng 7: 519-524.

Franklin, R.J., S.C. Barnett (2000) Olfactory ensheathing cells and CNS regeneration: the sweet smell of success? Neuron 28: 15-18.

Franssen, E.H., F.M. De Bree, A.H. Essing, A. Ramon-Cueto, J. Verhaagen (2008) Comparative gene expression profiling of olfactory ensheathing glia and Schwann cells indicates distinct tissue repair characteristics of olfactory ensheathing glia. Glia 56: 1285-1298.

Friedman, B., S.S. Scherer, J.S. Rudge, M. Helgren, D. Morrisey, J. McClain, D.Y. Wang, S.J. Wiegand, M.E. Furth, R.M. Lindsay, et al. (1992) Regulation of ciliary neurotrophic factor expression in myelin-related Schwann cells in vivo. Neuron 9: 295-305.

Galla, T.J., S.V. Vedecnik, J. Halbgewachs, S. Steinmann, C. Friedrich, G.B. Stark (2004) Fibrin/Schwann cell matrix in poly-epsiloncaprolactone conduits enhances guided nerve regeneration. Int J Artif Organs 27: 127-136.

Grant, G.A., R. Goodkin, M. Kliot (1999) Evaluation and surgical management of peripheral nerve problems. Neurosurgery 44: $825-$ 839, discussion 839-840.

Guerout, N., C. Duclos, L. Drouot, O. Abramovici, N. Bon-Mardion, Y. Lacoume, L. Jean, O. Boyer, J.P. Marie (2011a) Transplantation of olfactory ensheathing cells promotes axonal regeneration and functional recovery of peripheral nerve lesion in rats. Muscle Nerve 43: 543-551.

Guerout, N., A. Paviot, N. Bon-Mardion, C. Duclos, D. Genty, L. Jean, O. Boyer, J.P. Marie (2011b) Co-transplantation of olfactory ensheathing cells from mucosa and bulb origin enhances functional recovery after peripheral nerve lesion. PLoS One 6: e22816.

Guntinas-Lichius, O., D.N. Angelov, T.L. Tomov, J. Dramiga, W.F. Neiss, K. Wewetzer (2001) Transplantation of olfactory ensheathing cells stimulates the collateral sprouting from axotomized adult rat facial motoneurons. Exp Neurol 172: 70-80.

Guntinas-Lichius, O., K. Wewetzer, T.L. Tomov, N. Azzolin, S. Kazemi, M. Streppel, W.F. Neiss, D.N. Angelov (2002) Transplantation of olfactory mucosa minimizes axonal branching and promotes the recovery of vibrissae motor performance after facial nerve repair in rats. J Neurosci 22: 7121-7131.

Hobson, M.I., R. Brown, C.J. Green, G. Terenghi (1997) Inter-relationships between angiogenesis and nerve regeneration: a histochemical study. Br J Plast Surg 50: 125-131.
Hobson, M.I., C.J. Green, G. Terenghi (2000) VEGF enhances intraneural angiogenesis and improves nerve regeneration after axotomy. J Anat 197: 591-605.

Hood, B., H.B. Levene, A.D. Levi (2009) Transplantation of autologous Schwann cells for the repair of segmental peripheral nerve defects. Neurosurg Focus 26: E4.

Horch, R.E., H. Bannasch, J. Kopp, C. Andree, G.B. Stark (1998) Single-cell suspensions of cultured human keratinocytes in fibrin-glue reconstitute the epidermis. Cell Transplant 7: 309-317.

Imaizumi, T., K.L. Lankford, J.D. Kocsis (2000) Transplantation of olfactory ensheathing cells or Schwann cells restores rapid and secure conduction across the transected spinal cord. Brain Res 854: 70-78.

Kalbermatten, D.F., P.J. Kingham, D. Mahay, C. Mantovani, J. Pettersson, W. Raffoul, H. Balcin, G. Pierer, G. Terenghi (2008) Fibrin matrix for suspension of regenerative cells in an artificial nerve conduit. J Plast Reconstr Aesthet Surg 61: 669-675.

Kim, D.H., S.E. Connolly, D.G. Kline, R.M. Voorhies, A. Smith, M. Powell, T. Yoes, J.K. Daniloff (1994) Labeled Schwann cell transplants versus sural nerve grafts in nerve repair. J Neurosurg 80: 254-260.

Lakatos, A., R.J. Franklin, S.C. Barnett (2000) Olfactory ensheathing cells and Schwann cells differ in their in vitro interactions with astrocytes. Glia 32: 214-225.

Lin, H., F. Liu, C. Zhang, Z. Zhang, Z. Kong, X. Zhang, R.M. Hoffman (2011) Characterization of nerve conduits seeded with neurons and Schwann cells derived from hair follicle neural crest stem cells. Tissue Eng Part A 17: 1691-1698.

Lundborg, G. (1982) Regeneration after peripheral nerve injury - a biological and clinical problem. Lakartidningen 79: 2013-2017.

$\checkmark$ Mackinnon, S.E., A.L. Dellon (1990) A study of nerve regeneration across synthetic (Maxon) and biologic (collagen) nerve conduits for nerve gaps up to $5 \mathrm{~cm}$ in the primate. $\mathrm{J} \mathrm{Re}$ constr Microsurg 6: 117-121.

Meek, M.F., J.H. Coert (2008) US Food and Drug Administration/Conformit Europeapproved absorbable nerve conduits for clinical repair of peripheral and cranial nerves. Ann Plast Surg 60: 466-472.

Meyer, M., I. Matsuoka, C. Wetmore, L. Olson, H. Thoenen (1992) Enhanced synthesis of brainderived neurotrophic factor in the lesioned peripheral nerve: different mechanisms are responsible for the regulation of BDNF and NGF mRNA. J Cell Biol 119: 45-54.

Penna, V., B. Munder, G.B. Stark, E.M. Lang (2011) An in vivo engineered nerve conduit - fabrication and experimental study in rats. Microsurgery 31: 395-400.

Penna, V., G.B. Stark, E.M. Lang (2012) Longterm evaluation of the biogenic conduit for nerve gap bridging. Microsurgery, accepted. 
Radtke, C., A.A. Aizer, S.K. Agulian, K.L. Lankford, P.M. Vogt, J.D. Kocsis (2009a) Transplantation of olfactory ensheathing cells enhances peripheral nerve regeneration after microsurgical nerve repair. Brain Res 1254: 10-17.

Radtke, C., Y. Akiyama, J. Brokaw, K.L. Lankford, K. Wewetzer, W.L. Fodor, J.D. Kocsis (2004) Remyelination of the nonhuman primate spinal cord by transplantation of $\mathrm{H}$ transferase transgenic adult pig olfactory ensheathing cells. FASEB J 18: 335-337.

Radtke, C., J.D. Kocsis, P.M. Vogt (2009b) Chapter 22: transplantation of olfactory ensheathing cells for peripheral nerve regeneration. Int Rev Neurobiol 87: 405-415.

Radtke, C., K.L. Lankford, K. Wewetzer, T. Imaizumi, W.L. Fodor, J.D. Kocsis (2010) Impaired spinal cord remyelination by longterm cultured adult porcine olfactory ensheathing cells correlates with altered in vitro phenotypic properties. Xenotransplantation 17: 71-80.

Radtke, C., K. Wewetzer (2009) Translating basic research into clinical practice or what else do we have to learn about olfactory ensheathing cells? Neurosci Lett 456: 133-136.

Radtke, C., K. Wewetzer, K. Reimers, P.M. Vogt (2011) Transplantation of olfactory ensheathing cells as adjunct cell therapy for peripheral nerve injury. Cell Transplant 20: 145-152.

Ramon-Cueto, A., J. Avila (1998) Olfactory ensheathing glia: properties and function. Brain Res Bull 46: 175-187.

Rende, M., D. Muir, E. Ruoslahti, T. Hagg, S. Varon, M. Manthorpe (1992) Immunolocalization of ciliary neuronotrophic factor in adult rat sciatic nerve. Glia 5: 25-32.

Roet, K.C., K. Bossers, E.H. Franssen, M.J. Ruitenberg, J. Verhaagen (2011) A meta-analysis of microarray-based gene expression studies of olfactory bulb-derived olfactory ensheathing cells. Exp Neurol 229: 10-45.
Sasaki, M., K.L. Lankford, M. Zemedkun, J.D. Kocsis (2004) Identified olfactory ensheathing cells transplanted into the transected dorsal funiculus bridge the lesion and form myelin. J Neurosci 24: 8485-8493.

Schroder, J.M., R. May, J. Weis (1993) Perineurial cells are the first to traverse gaps of peripheral nerves in silicone tubes. Clin Neurol Neurosurg 95 (suppl): S78-S83.

Sinis, N., H.E. Schaller, S.T. Becker, B. Schlosshauer, M. Doser, H. Roesner, S. Oberhoffner, H.W. Muller, M. Haerle (2007) Long nerve gaps limit the regenerative potential of bioartificial nerve conduits filled with Schwann cells. Restor Neurol Neurosci 25: 131-141.

Sinis, N., H.E. Schaller, C. Schulte-Eversum, B. Schlosshauer, M. Doser, K. Dietz, H. Rosner, H.W. Muller, M. Haerle (2005) Nerve regeneration across a $2-\mathrm{cm}$ gap in the rat median nerve using a resorbable nerve conduit filled with Schwann cells. J Neurosurg 103: 10671076.

Smith, P.M., F.J. Sim, S.C. Barnett, R.J. Franklin (2001) SCIP/Oct-6, Krox-20, and desert hedgehog mRNA expression during CNS remyelination by transplanted olfactory en sheathing cells. Glia 36: 342-353.

Takami, T., M. Oudega, M.L. Bates, P.M. Wood, N. Kleitman, M.B. Bunge (2002) Schwann cell but not olfactory ensheathing glia transplants improve hindlimb locomotor performance in the moderately contused adult rat thoracic spinal cord. J Neurosci 22: 66706681.

Tarlov, I.M., J.A. Epstein (1945) Nerve grafts: the importance of an adequate blood supply. Brain 68: 49-71.

Terzis, J.K., T.G. Skoulis, P.N. Soucacos (1995) Vascularized nerve grafts. A review. Int Angiol 14: 264-277.

Terzis, J.K., D.D. Sun, P.K. Thanos (1997) Historical and basic science review: past, present, and future of nerve repair. J Reconstr Microsurg 13: 215-225.
Varejao, A.S., A.M. Cabrita, M.F. Meek, M. Fornaro, S. Geuna, M.G. Giacobini-Robecchi (2003) Morphology of nerve fiber regeneration along a biodegradable poly (DLLAepsilon-CL) nerve guide filled with fresh skeletal muscle. Microsurgery 23: 338-345.

Verdú, E., X. Navarro, G. Gudino-Cabrera, F.J. Rodriguez, D. Ceballos, A. Valero, M. NietoSampedro (1999) Olfactory bulb ensheathing cells enhance peripheral nerve regeneration. Neuroreport 10: 1097-1101.

Wewetzer, K., G. Brandes (2006) Axonal signalling and the making of olfactory ensheathing cells: a hypothesis. Neuron Glia Biol 2: 217224.

Wewetzer, K., C. Grothe, P. Claus (2001) In vitro expression and regulation of ciliary neurotrophic factor and its alpha receptor subunit in neonatal rat olfactory ensheathing cells. Neurosci Lett 306: 165-168.

Wewetzer, K., C. Heiniger, B. Seilheimer (1996) An improved cell-ELISA for the differential screening of antibodies against cell surface molecules of viable adherent Schwann cells. J Immunol Methods 191: 171-178.

Wewetzer, K., C. Radtke, J. Kocsis, W. Baumgartner (2011) Species-specific control of cellular proliferation and the impact of large animal models for the use of olfactory ensheathing cells and Schwann cells in spinal cord repair. Exp Neurol 229: 80-87.

Wewetzer, K., E. Verdú, D.N. Angelov, X. Navarro (2002) Olfactory ensheathing glia and Schwann cells: two of a kind? Cell Tissue Res 309: 337-345.

Widenfalk, J., K. Lundstromer, M. Jubran, S. Brene, L. Olson (2001) Neurotrophic factors and receptors in the immature and adult spinal cord after mechanical injury or kainic acid. J Neurosci 21: 3457-3475.

Woodhall, E., A.K. West, M.I. Chuah (2001) Cultured olfactory ensheathing cells express nerve growth factor, brain-derived neurotrophic factor, glia cell line-derived neurotrophic factor and their receptors. Brain Res Mol Brain Res 88: 203-213. 